\title{
Goodbye RAE, hello REF
}

Our many non-UK readers will, we trust, forgive us for devoting this editorial to the latest development in the uk government's efforts to quantify the quality of research in order to apportion funding. The implications of the REF, or Research Excellence Framework, are potentially as ugly as its title. They include a proposal to measure the 'impact' of work on society - specifically on government policy, industry and professional practice - rather than on scholarship and the speculative development of disciplines in themselves.

The burden of proving 'impact' will fall on the universities, diverting more time from actual research. Intentionally or not, the long-term implications for the humanities and for speculative science appear particularly grievous, and have been widely rehearsed in the national press, on numerous blogs, and even in a characteristically acerbic prime-time radio broadcast by Clive James. The near impossibility of finding suitable 'metrics' to assess impact means that funding for the humanities in particular will inevitably be further reduced. By rejecting as impractical the evaluation of the impact of the work of individuals, the REF as proposed systematically devalues the traditional basis of scholarship.

Not the least of the absurdities attending this new framework is the assumption that high-impact research is, by definition, 'excellent'. Looking back over the last half-century during which architectural research has gradually become established in universities, what work could claim the most direct impact on practice? An early and laudable example might be the advocacy of low-rise perimeter development that came out of the Centre for Land Use and Built Form Studies at Cambridge University and changed assumptions about how to achieve high densities in housing. The consequences of other influential endeavours now appear less positive: the supposed environmental advantages of deep-plan, mechanically ventilated, artificially-lit buildings; the pervasive impact of 'design methods' in promoting sprawling, formless plans; 'optimally' planned hospitals that ignored the emotional and psychological needs of patients. Under the REF, these and doubtless many other impactful endeavours now in disrepute would have been automatically deemed excellent and given more funding at the expense of work that could demonstrate no such influence.

Architecture remains, as Inge Mette Kirkeby reminds us (pp. 307-313), a notoriously difficult field into which to infiltrate the results of empirical research, let alone one in which to measure the impact of, say, a major monograph on a leading architect or a theoretical treatise. Architectural influence, as Charles Jencks once wrote, 'comes out of the barrel of a 6в pencil' and, by comparison with the glossy monthlies, the demonstrable influence on practice of the work published in arq is perhaps modest. Yet while that is not the sole, or even the most important, reason for the journal's existence, we remain committed to its founder's aspiration to consolidate links between academia and practice. To that end we have introduced a new section with effect from this issue. Entitled 'Criticism', it reflects our belief that a vital aspect of architectural research involves reporting the insights gained by the close examination of buildings. The opening contribution (pp. 220-230) is a characteristically thoughtful piece by Peter Blundell Jones; it is about half the word-count of our full-length papers, and we would welcome more such contributions.

We would also be delighted to receive letters on the REF. While the period for official consultation ends as this issue goes to press, its implications are sure to be debated for months and years to come. Creativity has long eluded quantitative measurement and the ideas that sustain architecture and architects remain multiple, shifting, contradictory and contingent. While creativity - as manifest in either design or research - is no predictable economic quantity, its importance is acknowledged by politicians, business leaders, industrialists and society at large. It seems particularly incumbent on architects to champion the virtues of speculative creative work whose impact is not always immediately apparent or straightforwardly open to the peculiar legitimation of quantitative metrics. We at arq hope to sustain and deepen this debate, and we welcome contributions from architects and researchers of all stripes. 


\section{architectural research quarterly}

\section{Subscribe now for 2010}

Innovative in conception, unique in breadth and generously illustrated, this pace-setting quarterly publication from Cambridge University Press links, on a global scale, the worlds of architectural practice and research. arq regularly includes extensive peer-reviewed sections on design, history, theory, construction, environmental design, information technology and practice - as well as structures, urbanism and documents. These are supplemented by letters, reports, reviews, a directory of specialist research centers and consultancies and an annual index. Each issue opens with a leader and closes with insight, a personal end-piece. In its ten year history, arq has published work from all over the world: from Chile to Sweden and from Japan to the Netherlands - with a strong representation from the United Kingdom and United States. arq, like architecture itself, is all-embracing and written by and for both practitioners and academics. It provides an outlet for all those who wish to disseminate their work to an international audience.
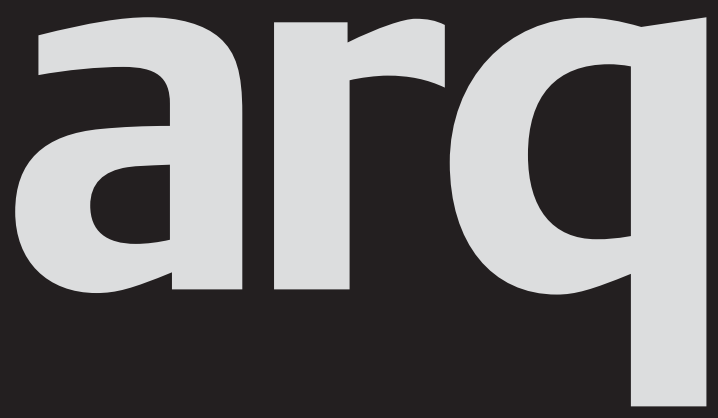

Please enter my subscription to arq: architectural research quarterly, volume 14, 2010

$\square$ E193/\$320 institutions print and electronic

$\square £_{31} / \$ 52$ students print only

$\square$ £43/\$66 individuals print only

EU residents only. VAT may be payable at your local rate if not registered.

Our VAT registration number: GB 214141614 If registered, your VAT registration no:

Total subscription payment $£ / \$$ EU residents only, if not registered add VAT at appropriate rate

Canadian residents, add 7\% GST \$

Total $\mathbf{E} / \$$

Name

Address

Payment enclosed

Cheque in sterling or US dollars

(payable to Cambridge University Press)

Credit Card - VISA | MasterCard | American Express (delete where applicable)

Card no

Expiry date

Signature

Photocopy this page and send your order to:

Journals Customer Services, Cambridge University Press, The Edinburgh Building, Cambridge, CB2 8RU, UK

$\mathrm{T}+44(0) 1223326070$

$\mathrm{F}+44(0) 1223315052$

E journals@cambridge.org

or in USA, Canada and Mexico send to:

Cambridge University Press, 32 Avenue of the

Americas, New York NY 10013-2473, USA

T (914) 9379600

F (914) 9374712

E journals_subscriptions@cup.org 